Akira Hirano • Hisaki Nagai • Haruhito Harada Yoshie Terada $\cdot$ Syunsuke Haga $\cdot$ Tetsuro Kajiwara Mitsuru Emi

\title{
Nine novel single-nucleotide polymorphisms in the integrin $\beta 4$ (ITGB4) gene in the Japanese population
}

Received: September 13, 2000 / Accepted: October 6, 2000

\begin{abstract}
We identified nine single-nucleotide polymorphisms (SNPs) in the human integrin $\beta 4$ (ITGB4) gene (17q24-q25), which encodes a cell-surface receptor, by screening all exons and exon-intron boundaries. Seven of these SNPs were present in coding regions and two in intronic sequences; four of the coding SNPs involved amino-acid substitutions. As the gene is implicated in the tumorigenesis of breast cancers, the polymorphic sites will serve as useful markers not only for distinguishing alleles in loss of heterozygosity (LOH) analyses but also for studying genetic susceptibility to malignancies in humans.
\end{abstract}

Key words Integrin $\beta 4$ gene $\cdot$ Single nucleotide polymorphism - Chromosome 17q24-25 · Cancer · Japanese

\section{Introduction}

Integrins comprise a large family of cell-surface receptors, each of them composed of two subunits, $\alpha$ and $\beta$. Integrin $\beta 4$ (ITGB4) interacts with $\alpha 6$; the $\alpha 6 / \beta 4$ heterodimer binds to laminin and is involved in the formation and maintenance of hemidesmosomes. Germline mutations of the ITGB4 gene have been identified in patients with epidermolysis bullosa, an autosomal recessive genodermatosis (Vidal et al. 1995). Natali et al. (1992) have documented underexpression of the ITGB 4 gene in primary and metastatic breast cancers, suggesting that alteration of this gene contributes to carcinogenesis and/or metastasis in that disease. By screening its entire coding region for sequence

A. Hirano $\cdot$ H. Nagai $\cdot$ H. Harada $\cdot$ Y. Terada $\cdot$ M. Emi $(\bowtie)$

Department of Molecular Biology, Institute of Gerontology, Nippon Medical School, 1-396 Kosugi-cho, Nakahara-ku, Kawasaki 211-8533, Japan

Tel. +81-44-733-5230; Fax +81-44-733-5192

e-mail:memi@nms.ac.jp

A. Hirano $\cdot$ S. Haga $\cdot$ T. Kajiwara

Department of Surgery, Second Hospital, Tokyo Women's Medical

University, Tokyo, Japan variations, using polymerase chain reaction/single-strand conformation polymorphism analysis (PCR-SSCP), we identified nine single-nucleotide polymorphisms (SNPs) in the ITGB4 gene in a Japanese population sample.

\section{Subjects and methods}

DNA samples. Informed consent, in the formal style of the hospital, was obtained from 48 healthy Japanese volunteers. Genomic DNA was prepared from each blood sample according to the standard protocols.

PCR conditions. Each PCR was performed in a volume of $30 \mu$ l, containing $100 \mathrm{ng}$ genomic DNA, $10 \mathrm{mM}$ Tris- $\mathrm{HCl}$ $(\mathrm{pH} 8.3), 50 \mathrm{mM} \mathrm{KCl}, 1.5 \mathrm{mM} \mathrm{MgCl} 2,0.01 \%$ gelatin, $200 \mu \mathrm{M}$ of each dNTP, 10 pmol of each primer, and 0.1 unit of Taq polymerase, as described previously (Tsukamoto et al. 1998). We used 54 primer sets to screen the entire coding sequence of the ITGB4 gene (exons 2-41). The primer sets for the eight regions found to contain SNPs are shown in Table 1 (two variant sites were found in intron 25). Cycling conditions were: $94^{\circ} \mathrm{C}$ for $3.5 \mathrm{~min}$, then 30 cycles of $94^{\circ} \mathrm{C}$ for $1 \mathrm{~min}, 55^{\circ} \mathrm{C}-68^{\circ} \mathrm{C}$ for $1 \mathrm{~min}$, and $72^{\circ} \mathrm{C}$ for $1 \mathrm{~min}$, with final extension for $5 \mathrm{~min}$ at $72^{\circ} \mathrm{C}$, in a Gene Amp PCR 9600 System (Perkin Elmer Cetus, Norwalk, CT, USA). Annealing temperatures were adjusted according to the melting temperature of each pair of primers.

SSCP analysis. A $10 \mathrm{ng}$ aliquot of each PCR product was heat-denatured in the presence of $50 \%$ formamide, and electrophoresed for $11 \mathrm{~h}$ at $10 \mathrm{~V} / \mathrm{cm}$ and room temperature in an $8 \%$ polyacrylamide gel, with and without $10 \%$ glycerol in $0.5 \times$ TBE $(1 \times$ TBE; $89 \mathrm{mM}$ Tris-borate, $89 \mathrm{mM}$ boric acid, 2 mM EDTA; pH 8.0) (Harada et al. 1992). DNA fragments were detected with a PlusOne DNA silverstaining kit (Amersham Pharmacia Biotech, Uppsala, Sweden), used according to the manufacturer's instructions.

DNA sequencing. Variant bands were used directly as templates for further amplification. The DNA sequence of each 
PCR product was determined using an Applied Biosystems model 377 DNA sequencer (Perkin Elmer Cetus).

\section{Results and discussion}

A total of healty 48 Japanese individuals were genotyped for sequence variations that might be present in any exon or exon-intron boundary of the ITGB4 gene. We identified nine SNPs, of which seven were located in coding regions and two in intronic sequences. Four of the coding SNPs reflected amino-acid substitutions. Genotypes and allele frequencies are summarized in Table 2.

The human ITGB4 gene was originally mapped to chromosome 17q11-qter by analysis of human-rodent somatic

Table 1. Primer sequences to amplify eight regions which contain SNPs

\begin{tabular}{|c|c|c|}
\hline $\begin{array}{l}\text { Name of } \\
\text { primer }\end{array}$ & Nucleotide sequences & $\begin{array}{l}\text { Product } \\
\text { size (bp) }\end{array}$ \\
\hline Exon $5-1 F$ & 5'-GCCAGGGAATGGGTGCTGCC-3' & 154 \\
\hline Exon 5-1R & 5'-TAGCCAGGCTGAGCATGGGG-3' & \\
\hline Exon $15 \mathrm{~F}$ & 5'-ACAGCTGGCTCACTGGTGC-3' & 163 \\
\hline Exon $15 R$ & 5'-ACGCCCACACCTCGTAGGT-3' & \\
\hline Exon $21 \mathrm{~F}$ & 5'-GGTGACCACCTCCATCTCAC-3' & 179 \\
\hline Exon $21 \mathrm{R}$ & 5'-TCCGGCCAGGCCTAGTTCC-3' & \\
\hline Exon $25-2 \mathrm{~F}$ & 5'-GAAGCAGCTGCTGGTGGAGG-3' & 184 \\
\hline Exon $25-2 \mathrm{R}$ & 5'-CCACGTGGCCAGGTCGCAAT-3' & \\
\hline Exon $34-2 F$ & 5'-GCTAAGCACATCCТCCACCC-3' & 145 \\
\hline Exon $34-2 R$ & 5'-GAGAGGCAGGGTTGGCTGA-3' & \\
\hline Exon $35-2 \mathrm{~F}$ & 5'-TCGGGCTCAGATGAAAGGGT-3' & 130 \\
\hline Exon $35-2 \mathrm{R}$ & 5'-AGGACACTGTGGAGACAGGA-3' & \\
\hline Exon $39 \mathrm{~F}$ & 5'-GCATAGGCTGAAGGCATCTT-3' & 224 \\
\hline Exon 39R & 5'-TGGGGGTGAAGGAAAGGAC-3' & \\
\hline Exon $41 \mathrm{~F}$ & 5'-AAGCCAGGTCATTTAATGCCTC-3' & 214 \\
\hline Exon 41R & 5'-GACGCGCTAGTGGGACATGG-3' & \\
\hline
\end{tabular}

SNP, Single-nucleotide polymorphism cell hybrids (Hogervorst et al. 1991), but integrated mapping information in Genemap99 now locates this gene at 17q24-25. Human cancers derived from breast, esophagus, or ovary frequently show allelic losses on chromosome band 17q25. Moreover, a locus responsible for hereditary focal non-epidermolytic palmoplantar keratoderma (TOC), a condition associated with esophageal cancer, has been mapped to the same band. We ourselves have described frequent allelic losses and a common region of deletion at this chromosomal region in breast cancers (Fukino et al. 1999).

The cytoplasmic domain of ITGB4 activates the p21 pathway of growth arrest and apoptosis (Clarke et al. 1995). As the expression of ITGB4 is reduced in primary and metastatic breast cancer, the combined data suggest that the ITGB4 gene is a candidate for involvement in the allelic losses that occur on $17 \mathrm{q}$ in some tumors. The polymorphisms documented here will be useful not only for examining loss of heterozygosity (LOH) in the chromosomal regions where the ITGB4 gene is located (17q24-25) but also for studying associations between specific SNPs and cancer susceptibility.

\begin{abstract}
Acknowledgments This work was supported in part by special grants for Strategic Advanced Research on "Cancer" and "Genome Science" from the Ministry of Education, Science, Sports and Culture of Japan; by a Research Grant from the Ministry of Health and Welfare of Japan; and by a Research for the Future Program Grant of The Japan Society for the Promotion of Science.
\end{abstract}

\section{References}

Clarke AS, Lotz MM, Chao C, Mercurio AM (1995) Activation of the p21 pathway of growth arrest and apoptosis by the beta4 integrin cytoplasmic domain. J Biol Chem 270:22673-22676

Fukino K, Iida A, Teramoto A, Sakamoto G, Kasumi F, Nakamura Y, Emi M (1999) Frequent allelic loss at the TOC locus on 17q25.1 in primary breast cancers. Genes Chromosom Cancer 24:345-350

Table 2. Genotypes and allele frequencies of the integrin $\beta 4$ gene

\begin{tabular}{|c|c|c|c|c|c|c|c|}
\hline \multirow{2}{*}{$\frac{\text { Region }}{\text { Exon } 5}$} & \multirow{2}{*}{$\begin{array}{l}\text { Nucleotide change } \\
293 \mathrm{G}>\mathrm{A}\end{array}$} & \multirow{2}{*}{$\begin{array}{l}\text { Amino acid change } \\
\mathrm{R} 98 \mathrm{H}\end{array}$} & \multicolumn{3}{|c|}{ Genotypes $(n=48)$} & \multicolumn{2}{|c|}{$\begin{array}{l}\text { Allele } \\
\text { frequencies (\%) }\end{array}$} \\
\hline & & & $\begin{array}{l}\mathrm{G} / \mathrm{G} \\
47\end{array}$ & $\begin{array}{c}\mathrm{G} / \mathrm{A} \\
1\end{array}$ & $\begin{array}{l}\mathrm{A} / \mathrm{A} \\
0\end{array}$ & $\begin{array}{l}\mathrm{G} \\
99\end{array}$ & $\begin{array}{r}\mathrm{A} \\
1\end{array}$ \\
\hline Exon 15 & $1821 \mathrm{G}>\mathrm{A}$ & S607S & $\begin{array}{l}\mathrm{G} / \mathrm{G} \\
27\end{array}$ & $\begin{array}{l}\mathrm{G} / \mathrm{A} \\
14\end{array}$ & $\begin{array}{l}\mathrm{A} / \mathrm{A} \\
7\end{array}$ & $\begin{array}{l}\mathrm{G} \\
71\end{array}$ & $\begin{array}{l}\text { A } \\
29\end{array}$ \\
\hline Exon 21 & $2531 \mathrm{G}>\mathrm{T}$ & $\mathrm{R} 844 \mathrm{~L}$ & $\begin{array}{l}\mathrm{G} / \mathrm{G} \\
47\end{array}$ & $\begin{array}{c}\mathrm{G} / \mathrm{T} \\
1\end{array}$ & $\begin{array}{l}\mathrm{T} / \mathrm{T} \\
0\end{array}$ & $\begin{array}{l}\mathrm{G} \\
99\end{array}$ & $\begin{array}{l}\mathrm{T} \\
1\end{array}$ \\
\hline Intron 25 & $\begin{array}{l}2962+11 \\
G>A\end{array}$ & Intronic variant & $\begin{array}{l}\mathrm{G} / \mathrm{G} \\
47\end{array}$ & $\begin{array}{c}\mathrm{G} / \mathrm{A} \\
1\end{array}$ & $\begin{array}{l}\mathrm{A} / \mathrm{A} \\
0\end{array}$ & $\begin{array}{l}\mathrm{G} \\
99\end{array}$ & $\begin{array}{r}\mathrm{A} \\
1\end{array}$ \\
\hline Intron 25 & $\begin{array}{l}2962+18 \\
G>C\end{array}$ & Intronic variant & $\begin{array}{l}\mathrm{G} / \mathrm{G} \\
46\end{array}$ & $\begin{array}{c}\mathrm{G} / \mathrm{C} \\
2\end{array}$ & $\begin{array}{l}\mathrm{C} / \mathrm{C} \\
0\end{array}$ & $\begin{array}{l}\mathrm{G} \\
98\end{array}$ & $\begin{array}{c}\mathrm{C} \\
2\end{array}$ \\
\hline Exon 34 & $4311 \mathrm{G}>\mathrm{C}$ & P1437P & $\begin{array}{c}\mathrm{G} / \mathrm{G} \\
8\end{array}$ & $\begin{array}{l}\mathrm{G} / \mathrm{C} \\
29\end{array}$ & $\begin{array}{l}\mathrm{C} / \mathrm{C} \\
11\end{array}$ & $\begin{array}{l}\mathrm{G} \\
47\end{array}$ & $\begin{array}{l}\mathrm{C} \\
53\end{array}$ \\
\hline Exon $35^{\mathrm{a}}$ & $4496 \mathrm{C}>\mathrm{T}$ & S1499F & $\begin{array}{l}\mathrm{C} / \mathrm{C} \\
36\end{array}$ & $\begin{array}{l}\mathrm{C} / \mathrm{T} \\
11\end{array}$ & $\begin{array}{l}\mathrm{T} / \mathrm{T} \\
1\end{array}$ & $\begin{array}{l}\mathrm{C} \\
87\end{array}$ & $\begin{array}{l}\mathrm{T} \\
13\end{array}$ \\
\hline Exon 39 & $4845 \mathrm{G}>\mathrm{A}$ & G1615G & $\begin{array}{l}\mathrm{G} / \mathrm{G} \\
46\end{array}$ & $\begin{array}{c}\mathrm{G} / \mathrm{A} \\
2\end{array}$ & $\begin{array}{l}\mathrm{A} / \mathrm{A} \\
0\end{array}$ & $\begin{array}{l}\mathrm{G} \\
98\end{array}$ & $\begin{array}{r}\mathrm{A} \\
2\end{array}$ \\
\hline Exon 41 & $5123 \mathrm{C}>\mathrm{T}$ & P1708L & $\begin{array}{l}\mathrm{C} / \mathrm{C} \\
33\end{array}$ & $\begin{array}{l}\mathrm{C} / \mathrm{T} \\
11\end{array}$ & $\begin{array}{l}\mathrm{T} / \mathrm{T} \\
4\end{array}$ & $\begin{array}{l}\mathrm{C} \\
80\end{array}$ & $\begin{array}{l}\mathrm{T} \\
20\end{array}$ \\
\hline
\end{tabular}

${ }^{\mathrm{a}}$ Integrin $\beta 4$ contains alternatively spliced exon 35 
Harada H, Kimura A, Dong RP, Xu XP, Bhatia K, Sasazuki T (1992) Sequencing and population analysis of four novel HLA-DPA1 alleles. Hum Immunol 35:173-178

Hogervorst F, Kuikman I, Kessel AGV, Sonnenberg A (1991) Molecular cloning of the human $\alpha 6$ integrin subunit. Alternative splicing of $\alpha 6$ mRNA and chromosomal localization of the $\alpha 6$ and $\beta 4$ integrin. Eur J Biochem 199:425-433

Natali PG, Nicotra MR, Botti C, Mottolese M, Bigotti A, Segatto O (1992) Changes in expression of $\alpha 6 / \beta 4$ integrin heterodimer in primary and metastatic breast cancer. Br J Cancer 66:318-322
Tsukamoto K, Haruta K, Shiba T, Emi M (1998) Isolation and mapping of a polymorphic CA repeat sequence at the human interleukin 6 locus. J Hum Genet 43:71-72

Vidal F, Aberdam D, Miquel C, Christiano AM, Pulkkinen L, Uitto J, Ortonne JP, Meneguzzi G (1995) Integrin $\beta 4$ mutations associated with junctional epidermolysis bullosa with pyloric atresia. Nat Genet 10:229-234 